\title{
ANALISIS DETERMINAN STATUS GIZI DAN ANEMIA PADA REMAJA PUTRI DI DESA TUMBANG RUNGAN, KOTA PALANGKA RAYA
}

\author{
Ni Nyoman Sri Yuliani ${ }^{1}$, Elsa Trinovita ${ }^{2}$, Mikko Uriamapas Ludjen ${ }^{3}$ \\ ${ }^{1}$ Departemen Gizi, Fakultas Kedokteran Universitas Palangka Raya, Indonesia \\ 2 Departemen Farmakologi, Fakultas Kedokteran Universitas Palangka Raya, Indonesia \\ ${ }^{3}$ KSM Ilmu Kesehatan Anak, RSUD Doris Sylvanus Palangka Raya, Indonesia \\ E-mail : nyomigiziklinik@gmail.com
}

\begin{abstract}
ABSTRAK
Latar Belakang Masalah : kecenderungan peningkatan remaja dengan status gizi sangat kurus dank urus di Kalimantan Tengan berdasarkan data Riskesdas dapat menimbulkan permasalahan kesehatan, terutama pada remaja putri. Remaja putri menjadi kelompok paling berisiko mengalami kekurangan gizi dan anemia yang dapat mempengaruhi kesehatan reproduksi dan menentukan masa depan generasi selanjutnya. Masyarakat di Desa Tumbang Rungan kebanyakan memiliki social ekonomi menengah kebawah, Pendidikan yang rendah dan fasilitas serta informasi kesehatan yang terbatas rentan akan risiko kesehata. Program Tablet Tambah Darah diwilayah ini baru diaktifkan kembali, sehingga perlu dilakukan analisis kondisi status gizi, anemia dan faktor determinannya seperti status kesehatan dan gaya hidup remaja putri di wilayah ini.

Metode Penelitian : penelitian deskriptif analitik secara potong melintang. Sampel diambil dengan purposive sampling pada remaja putri di SMP Satu Atap Tumbang Rungan. Data penelitian meliputi data status gizi (berat badan, tinggi badan, IMT/U), status kesehatan (pemeriksaan hemoglobin, siklus menstruasi) dan gaya hidup ( sarapan pagi, asupan protein, aktivitas fisik, prestasi belajar).

Hasil: subyek penelitian sebanyak 24 orang mengalami status gizi kurus 8,3\%, anemia sebanyak 12,5\%. Terdapat hubungan antara status gizi dengan menstruasi $(\mathrm{p}=0,005)$. Factor determinan yang berisiko adalah sarapan pagi dan asupan pprotein yang kurang.

Kesimpulan : kejadian gizi kurang dan anemia pada remaja putri di SMp Satu Atap Tumbang Rungan disebabkan factor kebiasaan sarapan pagi dan asupan protein yang tidak memadai.
\end{abstract}

Kata kunci : gizi, anemia, remaja putri

\begin{abstract}
Purpose : the tendency of an increasement of malnutrition in adolescents in Central Kalimantan based on Riskesdas data can lead to health problems, especially in female adolescents. Female adolescents are the most at risk of experiencing malnutrition and anaemia which can affect reproductive health and determine the futute of the next generation. Communities in Tumbang Rungan village mostly have middle-to-low socioeconomic, low education and limited health facilities and health information which is vulnerable to health risks. Tablet Tambah Darah programme in this region has just been reactivated, it is necessary to analyze the condition of nutritional status, anaemia and its determinant factors such as health status and lifestyle of female adolescents in this region.

Method : this research used cross-sectional analytic descriptive. Samples were taken by purposive sampling in female adolescents in Junior secondary School Satu Atap of Tumbang Rungan. Data included nutritional status (weight, height, BMI/AZ), health status (haemoglobin, menstrual cycle) and lifestyle (breakfast, protein intake, physical activity, learning achievement)

Result: Total subject of this research were 24 female adolescents. Data shows that $8,3 \%$ underweight, $12,5 \%$ anaemia. There were a relationship between nutritional status and menstrual cycle $(\mathrm{p}=0,005)$. Determinant factors probably at risk are breakfast habit and lack of protein intake.

Conclussion: the incidence of underweight and anaemia in female adolescents in Junior Secondary School Satu Atap of Tumbang Rungan are due to the factors of breakfast habits and inadequate protein intake.
\end{abstract}

Keywords: nutrition, anaemia, female adolescents 


\section{PENDAHULUAN}

Remaja merupakan fase transisi dari masa anak-anak menuju masa dewasa. Perubahan tumbuh kembang seperti pertambahan tinggi badan, perubahan hormonal dan kematangan seksual serta perubahan kognitif dan emosional. World Health Organization (WHO) melaporkan sekitar seperlima dari penduduk dunia adalah remaja yang berumur 10-19 tahun dan sekitar 900 juta berada di negara sedang berkembang. Data di Indonesia menunjukkan bahwa sekitar $15 \%$ penduduk berusia remaja antara 10-19 tahun, dan hasil sensus penduduk 2010 jumlah populasi remaja (10-24 tahun) di Indonesia meningkat mencapai 63 juta jiwa atau sekitar 27\% dari total penduduk. Indonesia merupakan salah satu negara berkembang yang menghadapi masalah gizi pada kelompok usia remaja (Simbolon, 2013)

Hasil Riskesdas Kalimantan Tengah tahun 2018, status gizi remaja usia 13-15 tahun berdasarkan TB/U dan IMT/U adalah 29,58\% untuk prevalensi sangat pendek dan pendek, sedangkan prevalensi sangat kurus dan kurus adalah $7,57 \%$. Data ini cenderung mengalami peningkatan dibandingkan hasil Riskesdas 2013, status gizi remaja usia 13-15 tahun prevalensi sangat pendek sebesar $11 \%$, dan prevalensi sangat kurus sebesar 4\%. (Badan Penelitian dan Pengembangan Kesehatan Kementerian Kesehatan RI, 2018; Direktorat Gizi Masyarakat, 2018; Kementerian Kesehatan Republik Indonesia, 2018)

Timbulnya masalah gizi remaja pada dasarnya dikarenakan perilaku konsumsi makan yang salah, yaitu keseimbangan antara konsumsi nutrisi dengan kecukupan nutrisi yang dianjurkan, bila konsumsi nutrisi kurang dari kecukupan maka remaja akan mengalami gizi kurang dan sebaliknya jika konsumsi melebihi angka kecukupan maka remaja akan menderita gizi lebih dan obesitas. Kurus dan obesitas merupakan masalah gizi yang paling sering ditemui maka remaja dapat mengakibatkan prestasi akademik menurun (Permaesih and Herman, 2005; Nursari, 2009).

Anak-anak dan wanita usia subur (WUS) adalah kelompok yang paling berisiko, dengan perkiraan prevalensi anemia di dunia pada balita sebesar $47 \%$, pada wanita hamil sebesar $42 \%$, dan pada wanita yang tidak hamil usia 15-49 tahun sebesar 30 \%. Hasil Riskesdas 2013 ditemukan proporsi anemia pada remaja (15-24 tahun) sebesar 18,4\% dan hasil Riskesdas 2018 menunjukkan 23,8\% remaja perempuan belum mendapatkan Tablet Tambah Darah (TTD).(Badan Penelitian dan Pengembangan Kesehatan Kementerian Kesehatan RI, 2013, 2018) World Health Organization (WHO) menargetkan penurunan prevalensi anemia pada WUS sebesar $50 \%$ pada tahun 2025.

Remaja yang lebih sering mengalami anemia adalah remaja putri,karena dalam usia reproduksi setiap harinya memerlukan zat besi tiga kali lebih banyak dengan remaja putra. Hal ini disebabkan remaja putri mengalami menstruasi setiap bulannya. Hal tersebut diperparah dengan pola konsumsi remaja putri. Remaja putri masih kurang kesadaran dalam mengkonsumsi makanan bergizi dan zat besi $(\mathrm{Fe})$ dan masih kurangnya informasi diet yang benar.(Permaesih and Herman, 2005; Putri and Bengkulu, 2015) Belum terpenuhinya gizi seimbang tersebut terkait dengan diet yang salah dan pantang makanan tertentu yaitu keinginan remaja putri menjaga tubuhnya agar langsing sehingga semakin sedikit asupan zat besi yang dapat memenuhi kebutuhan mereka (Putri and Bengkulu, 2015).

Desa Tumbang Rungan merupakan bagian dari kota Palangka Raya yang dominasi masyarakatnya memiliki sosial ekonomi menengah kebawah menyebabkan daya beli terhadap kebutuhan primer pangan juga tidak besar. Informasi kesehatan dan fasilitas kesehatan yang minim sehingga rentan akan risiko kesehatan. Remaja perempuan di wilayah ini rata-rata disekolahkan di SMP dan SMU satu atap dengan kondisi bangunan masih menggunakan kayu. Berdasarkan survey awal ke puskesmas pembandu Tumbang Rungan, bahwa remaja perempuan di wilayah ini baru mendapat program TTD tahun ini.

Berdasarkan latar belakang peneliti ingin menganalisis kondisi status gizi dan anemia pada remaja perempuan di Desa Tumbang Rungan yang dihubungkan dengan faktor-faktor determinannya yaitu sarapan pagi, asupan protein, aktivitas fisik, siklus menstruasi dan prestasi belajar yang sebelumnya belum dilakukan di desa Tumbang Rungan.

\section{METODE PENELITIAN}

Penelitian ini menggunakan pendekatan kuantitatif dengan desain deskriptif analitik secara potong melintang, dilakukan di Kelurahan Tumbang Rungan, Palangka Raya mulai bulan April-Oktober 2019. Sampel penelitian diambil secara purposive sampling pada remaja putri di SMP Satu Atap desa Tumbang Rungan, Palangka Raya. Kriteria inklusi meliputi usia 13-16 tahun 
dan telah menstruasi. Kriteria eksklusi yaitu memiliki riwayat penyakit kronik (thalassemia, kanker, diabetes dan penyakit jantung) dan tidak hadir saat penelitian. Subyek penelitian menandatangi inform consent.

Variabel yang diteliti adalah status gizi, status kesehatan (anemia dan siklus menstruasi), dan gaya hidup (sarapan pagi, asupan protein, aktivitas fisik, prestasi belajar)

Pemeriksaan status gizi menggunakan indeks IMT/U (WHO) dengan mengukur berat badan dan tinggi badan menggunakan timbangan digital dengan ketelitian $0,1 \mathrm{~kg}$ dan microtoise dengan ketelitian $0,1 \mathrm{~cm}$ kemudian di plotting pada kurva pertumbuhan WHO. Pengisian kuesioner untuk data sarapan pagi, asupan protein/hari, menstruasi dan aktivitas fisik). Pemeriksaan anemia dilakukan dengan mengukur Hemoglobin menggunakan hemoglobinometer digital.

Analisis data menggunakan statistic (Statistical Package for the Social Sciences) secara deskriptif dengan analisis univariat dan bivariat (Fisher exact test)

\section{HASIL}

Gambaran umum subyek penelitian. Besar sampel yang memenuhi kriteria yaitu sebanyak 24 remaja putri. Sebaran responden berdasarkan umur didominasi umur 15 tahun $(54,2 \%)$. Berat badan responden bervariasi dengan rerata $44,2 \mathrm{~kg}$ dan tinggi badan rerata $152,8 \mathrm{~cm}$. Karakteristik subyek dapat dilihat pada tabel 1 .

Tabel 1. Karakteristik subyek penelitian $(\mathrm{N}=\mathbf{2 4})$

\begin{tabular}{llrr}
\hline No. & Karakteristik & Min-maks & \multicolumn{1}{c}{ Mean } \\
\hline 1 & Usia (tahun) & $12-15$ & 14 \\
\hline 2 & Berat badan $(\mathrm{kg})$ & $25,3-57,5$ & 44,2 \\
\hline 3 & Tinggi Badan $(\mathrm{cm})$ & $140-166,5$ & 152,8 \\
\hline
\end{tabular}

Gambaran kesehatan berdasarkan status gizi pada responden berdasarkan IMT/U didapatkan gizi kurus $8,3 \%$ sedangkan kondisi anemia berdasarkan pemeriksaan $\mathrm{Hb}$ didapatkan 12,5\% responden mengalami anemia. Siklus menstruasi didapatkan dominan sebanyak $70,8 \%$ siklus teratur. Gambaran status kesehatan pada table 2.

Tabel 2. Sebaran status kesehatan responden

Variabel $\mathrm{n} \quad \%$

\begin{tabular}{clc}
\hline \multicolumn{3}{l}{ Status Gizi (IMT/U) } \\
$-\quad$ Kurus & 2 & 8,3 \\
$-\quad$ Normal & 22 & 91,7
\end{tabular}

\begin{tabular}{lcc}
$-\quad$ Gemuk & 0 & 0 \\
Anemia & & \\
$-\quad$ Ya & 3 & 12,5 \\
$-\quad$ tidak & 21 & 87,5 \\
Siklus menstruasi & & \\
$-\quad$ teratur & 17 & 70,8 \\
$-\quad$ tidak teratur & 4 & 16,7 \\
$-\quad$ belum menarche & 3 & 12,5 \\
\hline
\end{tabular}

Hasil korespondensi gaya hidup responden pada table 3 didapatkan responden kebanyakan tidak sarapan pagi, tidak mendapat cukup asupan protein, aktivitas fisik kurang dan prestasi belajar kurang baik ditandai dengan $62,5 \%$ ranking diatas 5 besar dikelasnya.

Tabel 3. Sebaran gaya hidup responden

\begin{tabular}{|c|c|c|}
\hline Variabel & $\mathrm{n}$ & $\%$ \\
\hline \multicolumn{3}{|l|}{ Sarapan } \\
\hline - $\quad \mathrm{Ya}$ & 6 & 25 \\
\hline - $\quad$ Tidak & 18 & 75 \\
\hline \multicolumn{3}{|l|}{ Asupan protein } \\
\hline Cukup & 7 & 29,2 \\
\hline Tidak cukup & 16 & 66,7 \\
\hline \multicolumn{3}{|l|}{ Aktivitas fisik } \\
\hline - $\quad$ Cukup & 5 & 20,8 \\
\hline Kurang & 19 & 79,2 \\
\hline \multicolumn{3}{|l|}{ Prestasi belajar } \\
\hline - $\quad$ Rangking 5 besar & 9 & 37,5 \\
\hline - $\quad$ Rangking $>5$ besar & 15 & 62,5 \\
\hline
\end{tabular}

Pada table 4 didapatkan hubungan signifikan antara status gizi dengan siklus menstruasi. Sedangkan status gizi tidak berhubungan bermakna dengan variabel gaya hidup (table 5)

Tabel 4. Hubungan status gizi dan status kesehatan

\begin{tabular}{|c|c|c|c|c|c|}
\hline \multirow{3}{*}{ Variabel bebas } & \multicolumn{4}{|c|}{ Status gizi } & \multirow{3}{*}{$\mathrm{p}$} \\
\hline & \multicolumn{2}{|c|}{ Kurus } & \multicolumn{2}{|c|}{ normal } & \\
\hline & $\mathrm{n}$ & $\%$ & $\mathrm{n}$ & $\%$ & \\
\hline \multicolumn{6}{|l|}{ Anemia } \\
\hline - $\quad \mathrm{Ya}$ & 0 & 0 & 3 & 100 & 0,761 \\
\hline Tidak & 2 & 9,5 & 19 & 90,5 & \\
\hline \multicolumn{6}{|l|}{ Siklus menstruasi } \\
\hline - teratur & 0 & 0 & 17 & 100 & \\
\hline $\begin{array}{ll}\text { - } & \text { tidak teratur } \\
\text { dan belum } \\
\text { menarche }\end{array}$ & 2 & 28,6 & 5 & 71,4 & $0,005^{*}$ \\
\hline
\end{tabular}

Tabel 5. Hubungan status gizi dan gaya hidup

\begin{tabular}{lcccccc}
\hline \multirow{2}{*}{ Variabel bebas } & \multicolumn{4}{c}{ Status Gizi } & $\mathrm{P}$ \\
\cline { 2 - 4 } & \multicolumn{2}{c}{ Kurus } & \multicolumn{2}{c}{ Normal } & \\
\cline { 2 - 5 } & $\mathrm{n}$ & $\%$ & $\mathrm{n}$ & $\%$ & \\
\hline Sarapan & & & & & \\
- Ya & 0 & 0 & 6 & 100 & 0,554 \\
- Tidak & 2 & 11,1 & 16 & 88,9 &
\end{tabular}




\begin{tabular}{lccccc} 
Asupan protein & & & & & \\
- Cukup & 1 & 14,3 & 6 & 85,7 & 0,526 \\
- Tidak cukup & 1 & 6,3 & 15 & 93,8 & \\
$\begin{array}{l}\text { Aktivitas fisik } \\
\text { - Cukup }\end{array}$ & 0 & 0 & 5 & 100 & 0,620 \\
- $\quad$ Kurang & 2 & 10,5 & 17 & 89,5 & \\
$\begin{array}{l}\text { Prestasi belajar } \\
\text { - Rangking 5 }\end{array}$ & 0 & 0 & 9 & 100 & 0,380 \\
$\quad \begin{array}{l}\text { besar } \\
\text { - Rangking > 5 } \\
\text { besar }\end{array}$ & 2 & 13,3 & 13 & 86,7 & \\
\hline
\end{tabular}

\section{DISKUSI}

Total subyek yang mengikuti penelitian ini adalah 24 orang remaja putri dari SMP Satu Atap Tumbang Rungan dengan rentang usia 12-15 tahun. Data karakteristik subyek penelitian menunjukkan bahwa masih terdapat gizi kurang (kurus) sebanyak 8,3\% dan anemia sebanyak $12,5 \%$. Responden dengan status gizi kurang diketahui memiliki kebiasaan tidak makan pagi dan asupan protein yang tidak memadai. Sedangkan responden yang menderita anemia diketahui asupan proteinnya tidak mencukupi kebutuhan harian.

Sarapan pagi dan asupan protein memiliki peran penting dalam status gizi dan anemia pada remaja putri. Penelitian Kalsum (2018) menyebutkan bahwa remaja yang memiliki kebiasaan tidak sarapan pagi berisiko menderita anemia dua kali lipat lebih besar dibanding remaja dengan kebiasaan sarapan pagi secara rutin (Kalsum and Halim, 2016). Protein merupakan makronutrien yang dibutuhkan dalam pembentukan hemoglobin selain zat besi. Anemia menyebabkan rendahnya daya ingat dan daya konsentrasi berkurang sehingga akan mempengaruhi prestasi belajar.(Pratama, 2013) Berdasarkan data Riskesdas (2013) menunjukkan bahwa prevalensi status gizi anak umur 5 -12 tahun adalah $30,7 \%$ pendek, $11,2 \%$ kurus dan $18,8 \%$ gemuk. Sedangkan data anemia masih merupakan masalah kesehatan masyarakat Indonesia. Prevalensi anemia pada anak usia 5 - 12 tahun sebesar 29\%.(Badan Penelitian dan Pengembangan Kesehatan Kementerian Kesehatan RI, 2013)

Faktor utama penyebab anemia adalah asupan zat besi yang kurang dan terlihat dari kurangnya asupan pangan hewani pada pola makan penduduk Indonesia10 dan sarapan yang tertunda atau tidak sarapan akan menyebabkan tidak terpenuhinya asupan gizi yang dibutuhkan termasuk didalamnya asupan zat besi. Defisiensi Besi memiliki dampak yang besar bagi bayi dan anak dikemudian harinya seperti gangguan sistem imun, peningkatan angka kesakitan, kemerosotan perkembangan mental, capaian sekolah yang rendah dan gangguan fungsi pertumbuhan, dan juga memiliki dampak pada kecerdasan.(Utama, Sembiring and Sine, 2018). Pada penelitian ini didapatkan responden yang status gizi kurang dan responden dengan anemia memiliki prestasi belajar yang kurang.

Hasil penelitian ini juga didapatkan adanya hubungan bermakna antara status gizi dengan siklus menstruasi $(p=0,005)$. Status gizi berhubungan dengan siklus menstruasi pada remaja. Cadangan lemak dalam tubuh mempengaruhi jumlah insulin dan leptin. Kedua hormone tersebut berhubungan dengan sekresi Gonadotropin Releasing hormone (GnRH). Hormon GnRH ini akan menstimulasi sekresi folicel stimulating hormone (FSH) dan Luteinizing Hormone (LH) yang berperan dalam proses ovulasi dan steroidogenesis. Bilamana status gizi tidak baik, dapat menyebabkan gangguan menstruasi atau terlambat menarche karena kadar esterogen yang rendah.(Zalni, Harahap and Desfita, 2017)

Penelitian ini terdapat ketidakbermaknaan hubungan antara status gizi dengan kejadian anemia, sarapan pagi, asupan protein, aktivitas dan prestasi belajar. Hal ini dapat disebabkan perbedaan metode dan alat ukur serta jumlah sampel yang kemungkinan dapat mempengaruhi variasi change.

\section{KESIMPULAN}

Kejadian gizi kurang dan anemia pada remaja putri di SMP Satu Atap Tumbang Rungan menjadi permasalah gizi yang salah satunya disebabkan kebiasaan sarapan dan asupan protein yang kurang.

\section{SARAN}

Hasil penelitian dapat menjadi masukan informasi bagi petugas kesehatan setempat untuk dapat meningkatkan status kesehatan remaja putri.

\section{DAFTAR PUSTAKA}

Badan Penelitian dan Pengembangan Kesehatan Kementerian Kesehatan RI (2013) Riset Kesehatan Dasar. Jakarta.

Badan Penelitian dan Pengembangan Kesehatan Kementerian Kesehatan RI (2018) HASIL UTAMA RISKESDAS 2018. Jakarta. 
Direktorat Gizi Masyarakat (2018) Buku Saku Pemantauan Status Gizi Tahun 2017. Jakarta: Direktorat Jenderal Kesehatan Masyarakat, Kementerian Kesehatan.

Kalsum, U. and Halim, R. (2016) 'Kebiasaan Sarapan pagi Berhubungan dengan Kejadian Anemia pada Remaja di SMA Negeri 8 Muaro Jambi', Jurnal Penelitian Universitas Jambi, 18, pp. 9-18.

Kementerian Kesehatan Republik Indonesia (2018) Laporan Nasional RISKESDAS 2018 Provinsi Kalimantan Tengah. Jakarta.

Nursari, D. (2009) Gambaran Kejadian Anemia Pada Remaja Putri SMP Negeri 18 Kota Bogor. Universitas Isla Negeri Syarif Hidayatullah.

Permaesih, D. and Herman, S. (2005) 'Factors Influencing Anemia Among Adolescents', Bul.Penel.KEsehatan, 33(4), pp. 11-14.

Pratama, A. (2013) 'Hubungan antara Status Gizi, Sarapan, Asupan Gizi Sarapan, Kualitas dan Kuantitas Tidur Malam dengan Konsentrasi pada Siswa Kelas 7 SMP Negeri 239 Jakarta'.

Putri, R. and Bengkulu, K. (2015) 'Analisis Pola Makan dan Anemia Gizi Besi Pada Remaja Putri Kota Bengkulu', Jurnal Kesehatan Masyarakat Andalas, 10(1), pp. 11-18.

Simbolon, D. (2013) 'Model Prediksi Indeks Massa Tubuh Remaja Berdasarkan Riwayat Lahir dan Status Gizi Anak', Kesmas: National Public Health Journal, 8(1), p. 19. doi: 10.21109/kesmas.v8i1.337.

Utama, L. J., Sembiring, A. C. and Sine, J. G. L. (2018) 'Perilaku sarapan pagi kaitannya dengan status gizi dan anemia pada anak sekolah dasar', Jurnal Gizi Indonesia, 7(1), pp. 63-68.

Zalni, R., Harahap, H. and Desfita, S. (2017) 'Usia Menarche Pada Anak Perempuan Berhubungan Dengan Status Gizi, Konsumsi Makanan Dan Aktivitas Fisik', Jurnal Kesehatan Reproduksi, 8(2), pp. 153-161. doi: 10.22435/kespro.v8i2.6918.153-161. 